\title{
The modern and glacial overturning circulation in the Atlantic ocean in PMIP coupled model simulations
}

\author{
S. L. Weber ${ }^{1}$, S. S. Drijfhout ${ }^{1}$, A. Abe-Ouchi ${ }^{2}$, M. Crucifix ${ }^{3}$, M. Eby ${ }^{4}$, A. Ganopolski ${ }^{5}$, S. Murakami $^{6}$, \\ B. Otto-Bliesner ${ }^{7}$, and W. R. Peltier ${ }^{8}$ \\ ${ }^{1}$ Royal Netherlands Meteorological Institute (KNMI), De Bilt, The Netherlands \\ ${ }^{2}$ Center for Climate System Research, The University of Tokyo Kashiwa, Japan \\ ${ }^{3}$ Hadley Center for Climate Prediction and Research, Met Office, Exeter, UK \\ ${ }^{4}$ School of Earth and Ocean Sciences, University of Victoria, Victoria, Canada \\ ${ }^{5}$ Potsdam Institute for Climate Impact Research, Potsdam, Germany \\ ${ }^{6}$ Meteorological Research Institute, Tsukuba, and Frontier Research Center for Global Change, JAMSTEC, Yokohama, Japan \\ ${ }^{7}$ National Center for Atmospheric Research, Boulder, USA \\ ${ }^{8}$ Department of Physics, University of Toronto, Toronto, Canada
}

Received: 22 September 2006 - Published in Clim. Past Discuss.: 11 October 2006

Revised: 15 January 2007 - Accepted: 25 January 2007 - Published: 1 February 2007

\begin{abstract}
This study analyses the response of the Atlantic meridional overturning circulation (AMOC) to LGM forcings and boundary conditions in nine PMIP coupled model simulations, including both GCMs and Earth system Models of Intermediate Complexity. Model results differ widely. The AMOC slows down considerably (by 20-40\%) during the LGM as compared to the modern climate in four models, there is a slight reduction in one model and four models show a substantial increase in AMOC strength (by 10-40\%). It is found that a major controlling factor for the AMOC response is the density contrast between Antarctic Bottom Water (AABW) and North Atlantic Deep Water (NADW) at their source regions. Changes in the density contrast are determined by the opposing effects of changes in temperature and salinity, with more saline AABW as compared to NADW consistently found in all models and less cooling of AABW in all models but one. In only two models is the AMOC response during the LGM directly related to the response in net evaporation over the Atlantic basin. Most models show large changes in the ocean freshwater transports into the basin, but this does not seem to affect the AMOC response. Finally, there is some dependence on the accuracy of the control state.
\end{abstract}

Correspondence to: S. L. Weber

(weber@knmi.nl)

\section{Introduction}

Simulation of the glacial climate is a relevant excercise for general circulation models (GCMs) used to predict future climate changes. Most importantly, it provides an assessment of the accuracy of models' representation of climate change in response to changes in the forcings and boundary conditions. Whether direct inferences on future climate changes can be made based on the glacial climate is still under debate (Hargreaves et al., 2006). The glacial net forcing includes large contributions from other factors than greenhouse gas changes. Also, the climatic responses to increased greenhouse gas levels (future climate) and reduced levels (glacial climate) is not necessarily symmetric. Obviously, this holds for the response of the Atlantic meridional overturning circulation (AMOC) as climate models simulate a decline in circulation strength for a $\mathrm{CO}_{2}$ quadrupling (Gregory et al., 2005) while proxy data indicate a decline during glacials as well (see below). Nevertheless, such validation excercises should be attempted in order to gain understanding of the processes underlying climate change and to enhance confidence in model predictions of the climate of the next century.

The Paleoclimate Modeling Intercomparison Project (PMIP) has defined a standard set of forcings and boundary conditions for the Last Glacial Maximum (LGM) and pre-industrial climate in order to facilitate intercomparison among models and with paleoclimatic data (eg MassonDelmotte et al., 2005; Kageyama et al., 2006). During the first phase of PMIP, simulations were done with atmospheric GCMs. Now that simulations of the glacial climate with cou-

Published by Copernicus GmbH on behalf of the European Geosciences Union. 
pled atmosphere-ocean GCMs are feasible, it is possible to test the glacial AMOC against the available evidence from proxy data. Paleoclimatic data suggest that the overturning cell associated with North Atlantic Deep Water (NADW) formation was weaker than today (McManus et al., 2004), with enhanced intrusion of Antarctic Bottom Water (AABW) into the Atlantic basin (Duplessy et al., 1988; Labeyrie et al., 1992; Sarnthein et al., 1994; Curry and Oppo, 2005). Models, on the other hand, show a wide range of responses when comparing the glacial AMOC to the modern. The AMOC is intensified in some of the first coupled AO-GCM runs (Hewitt et al., 2001; Kitoh et al., 2001), while it is weakened in others (Peltier and Solheim, 2003; Shin et al, 2003). Considering this diversity of model results, it remains to be established which mechanisms are responsible for maintaining the glacial AMOC as it is reconstructed from proxy data.

Several hypotheses have been put forward in the literature on the dominant processes responsible for the reduced glacial overturning circulation. Sensitivity experiments with the UVic intermediate-complexity coupled model show that the glacial thermal forcing alone leads to stronger NADW formation, while diminished net evaporation over the Atlantic basin counteracts the thermal forcing resulting in reduced NADW (Schmittner et al., 2002). The glacial ocean exhibits two closely related equilibrium states in the CLIMBER-2 intermediate-complexity model, which differ in the location of deep-water formation (Ganopolski et al., 1998; Ganopolski and Rahmstorf, 2001). One is a stable "cold" mode with a slightly weakened AMOC, due to a salinity reduction in NADW compared to AABW, and the other a marginally unstable "warm" mode with intensified AMOC and a more northern formation of NADW. Finally, a weakened AMOC is associated with enhanced AABW formation induced by stronger equatorward sea-ice export in the Southern Ocean in the NCAR atmosphere-ocean (AO) GCM (Shin et al., 2003).

The purpose of the present paper is to carry out a model intercomparison study, analysing for the first time the modern and glacial circulation in the Atlantic ocean simulated by coupled atmosphere-ocean models within the framework of PMIP. More specifically, we examine if processes invoked in the literature to explain AMOC changes in a certain model also work in other models. We do not attempt a detailed comparison to the available proxy data, but focus on the role of different mechanisms in the simulations. The outline of this paper is as follows. Section 2 briefly describes the models and experimental design, while Sect. 3 gives an account of simulated AMOC changes. Sections 4 and 5 focus on two important contributors to AMOC changes, namely the Atlantic freshwater budget and the relative roles of AABW and NADW. Finally, Sect. 6 contains a discussion and conclusions.

\section{Models and experimental design}

The present intercomparison study includes five PMIP2 coupled AO simulations, see Table 1. Two of the GCMs (CCSM and HadCM) start from the cold state of a previous coupled LGM simulation, whereas one GCM (MIROC) is initialized from modern conditions. We include two Earth system Models of Intermediate Complexity (EMICs; ECBilt/CLIO and the UVic model), which both consist of a simplified atmospheric component while the ocean/sea-ice component is similar in complexity to those in the AO-GCMs. The two EMIC runs start from a warm state, but have each been run for a few millennia under glacial forcings and boundary conditions.

The PMIP2 forcings for the LGM, which occurred ca. 21000 years Before Present (21 kyr BP), are the changes in solar insolation and the reduced concentrations of greenhouse gas levels relative to the pre-industrial control state. Boundary conditions are the ICE-5G ice-sheet reconstruction (Peltier, 2004) and the changes in land-sea mask consistent with ICE-5G. The lowering of sea level due to the presence of large continental ice sheets results in exposed land. Most notably in the circum-Atlantic area is the closure of Bering Strait. Vegetation and other land-surface characteristics are unchanged with respect to the control simulation. The forcings and boundary conditions are detailed on the PMIP2 website (http://www-lsce.cea.fr/pmip2/).

For some of the coupled AO models included in the present analysis earlier LGM simulations have been published, using the ICE-4G ice-sheet reconstruction (Peltier, 1994) in which the Fennoscandian ice sheet extended far east over northwestern Siberia. These so-called PMIP1.5 runs exist for HadCM (Hewitt et al., 2001), UVic (Schmittner et al., 2002), the NCAR CCSM (Shin et al., 2003) and the University of Toronto version of the CCSM model (CCSM1.4; Peltier and Solheim, 2003). In the present study, the most recent PMIP2 simulations are used for CCSM (Otto-Bliesner et al., 2006) and UVic. For HadCM we analyse both the PMIP2 and the earlier PMIP1.5 runs, as they exhibit a qualitatively different AMOC response. In addition, we analyse the early MRI (Kitoh et al., 2001) and CCSM1.4 runs (Peltier and Solheim, 2003) as well as the "cold" glacial state found in CLIMBER-2 (Ganopolski et al., 1998). The latter model is an EMIC consisting of a zonally-averaged three-basin ocean component coupled to a statistical-dynamical atmosphere.

More information on the models can be found in the references given above for the LGM simulations and on the PMIP2 website. A number of the recent PMIP2 LGM simulations have not been published yet. For detailed information on these models we refer to the relevant publications on the control state (HadCM3M2 - Gordon et al., 2000; MIROC3.2 - Hasumi and Emori, 2004; ECBilt/CLIO - Vries and Weber, 2005; UVic - Weaver et al., 2001). The output data for these runs is available from the PMIP database, as indicated in Table 1 , or directly from the modelling groups. All simulations 
Table 1. The simulations that are included in the analysis, abbreviated model names, availability (yes/no) of model output in the PMIP database, type of atmospheric component, the number of ocean horizontal grid points (lonxlat) and depth levels, the number of years at the end of each simulation used to compute the overturning streamfunction in Sect. 3 and the mean seasonal cycle in Sect. 4, and the time periods for which the model allows for transport through Bering Strait. The ocean component of CLIMBER-2 contains three zonally-averaged basins.

\begin{tabular}{|c|c|c|c|c|c|c|}
\hline model (country) & abbreviation & in $\mathrm{DB}$ ? & type of atmosphere & ocean grid & output segment & Bering Strait \\
\hline \multicolumn{7}{|l|}{ PMIP2 simulations } \\
\hline CCSM3.0 (USA) & CCSM & yes & GCM & $320 \times 395 \times 40$ & 10 & $0 \mathrm{k}$ \\
\hline HadCM3M2 (UK) & Hadl2 & yes & GCM & $288 \times 144 \times 20$ & 100 & $0 \mathrm{k}$ \\
\hline MIROC3.2 (Japan) & MIROC & yes & GCM & $256 \times 192 \times 43$ & 50 & $0 \mathrm{k}, 21 \mathrm{k}$ \\
\hline ECBilt2/CLIO (Netherlands) & ECBilt & yes & quasi-geostr. GCM & $120 \times 60 \times 20$ & 100 & $0 \mathrm{k}$ \\
\hline UVic ESCM2.7 (Canada) & UVic & no & moist EBM & $100 \times 100 \times 19$ & 10 & - \\
\hline \multicolumn{7}{|l|}{ PMIP1.5-type simulations } \\
\hline HadCM3 (UK) & Hadl1.5 & yes & GCM & $288 \times 144 \times 20$ & 50 & $0 \mathrm{k}$ \\
\hline MRI-CGCM1 (Japan) & MRI & no & GCM & $144 \times 111 \times 23$ & 40 & $0 \mathrm{k}, 21 \mathrm{k}$ \\
\hline CCSM1.4 (Canada) & UTor & no & GCM & $100 \times 116 \times 25$ & 100 & - \\
\hline CLIMBER-2 (Germany) & ClimC & no & stat.dyn. model & $3 * x 72 \times 20$ & 100 & - \\
\hline
\end{tabular}

have been integrated long enough to have allowed the deep ocean temperature to adjust to glacial forcings and boundary conditions. Remaining imbalances in the deep ocean salinity for the modern and the glacial climate are assessed in Sect. 4.2, where we compute the terms of the Atlantic freshwater budget. Local freshwater flux corrections are used in the MRI model (Kitoh et al., 2001), whereas ECBilt applies basin-scale corrections and a local correcion in the southern Atlantic (Vries and Weber, 2005).

Some variations exist among the PMIP simulations in the applied glacial boundary conditions, mostly the handling of ice-sheet melt and the adaptation of the river routing scheme. In all simulations except Hadl2 the maximum snow depth is set to a fixed limit (of 1-2 m) both for the control and the LGM state. When the snow depth exceeds this limit, excess snow melts and becomes runoff. In Hadl2 a spatially varying freshwater correction is used to close the water budget, which was calibrated such as to compensate for the long-term accumulation of snow over the adjacent ice sheets. The correction is prescribed for the high-latitude oceans (poleward of $40^{\circ} \mathrm{N}$ in the Atlantic/Arctic ocean and poleward of $50^{\circ} \mathrm{S}$ in the Southern ocean). For the Atlantic/Arctic basin this correction is equivalent to a freshwater forcing of $0.033 \mathrm{~Sv}$ for the modern run and $0.054 \mathrm{~Sv}$ for the LGM run.

The present-day river pathways are used for the LGM in most models. Only Hadl2 and ECBilt adopt a slight modification. In the Hadl2 run the river pathways were altered according to the output from a river routing model forced with ICE-5G topography. In ECBilt those catchment areas that are covered by ice-sheets during the LGM are added to the catchment of a nearby non-covered river. The zonal-mean ocean component of CLIMBER-2 includes a parameterization of freshwater transport due to the subpolar gyre and seaice export in the northern Atlantic, which is modified for glacial conditions resulting in reduced transport (Ganopolski and Rahmstorf, 2001). Mean ocean salinity includes an increase of 1 PSU in the LGM initial state of CCSM (Shin et al., 2003), but is left unchanged in all other PMIP runs.

\section{The Atlantic overturning circulation}

A number of characteristics of the Atlantic overturning circulation are given in Table 2 for the nine different simulations. For the control state the maximum of the main circulation cell associated with the formation of NADW varies between 14 and $27 \mathrm{~Sv}$. The downward branch of this cell, as indicated by the latitude of the $10 \mathrm{~Sv}$ contour at the depth of the AMOC maximum, is located at $56-65^{\circ} \mathrm{N}$. This implies that deep water is formed reasonably close to the observed locations (Dickson and Brown, 1994). The division between the main cell and the reversed deep cell associated with the intrusion of AABW is characterised by the depth of the zero contour at the southern boundary of the Atlantic basin. It ranges between 2 and $3.5 \mathrm{~km}$. It follows that a number of models overestimate the overturning strength, while the depth of the main cell is generally underestimated.

A relatively larger contribution of AABW as compared to NADW during the LGM was deduced on the basis of low $\delta^{13} C$ values below $2000-2500 \mathrm{~m}$ depth in the northern Atlantic by a number of authors (Duplessy et al., 1988; Labeyrie et al., 1992; Sarnthein et al., 1994; Curry and Oppo, 2005). However, passive tracers provide little information on oceanic volume transport (Legrand and Wunsch, 1995; Ruttberg and Peacock, 2006), as their end-member values are largely unknown. Better constraints are obtained from $\mathrm{Pa} / \mathrm{Th}$ data, which indicate a slowdown of the AMOC during the LGM as compared to the present climate by ca. $30 \%$ and probably less (McManus et al., 2004). Most likely At- 
Table 2. Characteristics of the AMOC: the maximum strength $\Psi_{\max }$ (in Sv) occurring at the given depth (in km), the latitude of the $10 \mathrm{~Sv}$ contour at this depth, the maximum $\Psi_{\mathrm{S}}$ of the reversed cell associated with AABW at the southern boundary of the Atlantic basin and the depth (in km) of the division between NADW and AABW at the southern boundary. The first four columns give values for $0 \mathrm{k}$, the second four those for $21 \mathrm{k}$ and the last column gives the response in $\Psi_{\max }$ (in Sv and as a percentage of the modern value).

\begin{tabular}{l|llll|llll|c}
\hline & $\Psi_{\max }($ depth) & $10 \mathrm{~Sv}$ & $\Psi_{\mathrm{S}}$ & division & $\Psi_{\max }($ depth) & $10 \mathrm{~Sv}$ & $\Psi_{\mathrm{S}}$ & division & $\Delta \Psi_{\max }$ \\
\hline PMIP2 & & at 0 kyr & BP & & & at 21 kyr & BP & & \\
\hline CCSM & $20.8(1.4)$ & 61 & -3.7 & 3.0 & $17.3(0.9)$ & 48 & -6.6 & 2.3 & $-3.5(17 \%)$ \\
Had12 & $17.4(1.0)$ & 63 & -5.7 & 1.8 & $16.9(1.0)$ & 63 & -5.9 & 2.4 & $-0.5(3 \%)$ \\
MIROC & $18.8(1.1)$ & 62 & -4.3 & 2.9 & $26.1(1.3)$ & 61 & -2.4 & 3.4 & $+7.3(39 \%)$ \\
ECBilt & $13.8(0.9)$ & 63 & -3.4 & 2.6 & $18.4(1.7)$ & 57 & 0.0 & 5.0 & $+4.7(25 \%)$ \\
UVic & $20.4(1.0)$ & 59 & -3.0 & 3.1 & $14.2(1.3)$ & 47 & -3.6 & 2.7 & $-6.2(30 \%)$ \\
\hline PMIP1.5-type & & & & & & & & & \\
\hline Had11.5 & $18.3(1.0)$ & 65 & -6.2 & 2.4 & $21.7(1.0)$ & 61 & -6.5 & 2.4 & $+3.4(19 \%)$ \\
MRI & $27.1(1.0)$ & 65 & -4.8 & 2.2 & $29.5(1.3)$ & 63 & -2.5 & 2.9 & $+2.4(9 \%)$ \\
UTor & $21.6(0.8)$ & 56 & -3.1 & 2.9 & $13.1(0.7)$ & 37 & -6.6 & 1.9 & $-5.1(40 \%)$ \\
ClimC & $23.0(1.0)$ & 63 & -2.9 & 3.5 & $18.4(0.5)$ & 55 & -5.7 & 2.5 & $-4.6(20 \%)$ \\
\hline
\end{tabular}

lantic deep-water was formed at more southern locations than today (Labeyrie et al., 1992). At present NADW is warm and saline, whereas AABW is cold and relatively fresh. Since AABW cannot cool below the freezing point, it must have been saltier than today to balance the higher density of NADW (Zahn and Mix, 1991). During the LGM the Southern Ocean indeed contained the saltiest deep water (Adkins et al., 2002).

In four model simulations (CCSM, UVic, UTor and ClimC) the AMOC slows down during the LGM as compared to the control state, see Table 2. In those runs the maximum overturning strength $\Psi_{\max }$ is reduced by 3-6 Sv (20$40 \%$ ). In Hadl2 there is a slight reduction (by $3 \%$ ), while in four simulations (MIROC, ECBilt, Hadl1.5 and MRI) the AMOC strength increases by $2-7 \mathrm{~Sv}(10-40 \%)$. In all simulations the location of the downward branch shifts southward or remains at the same latitude. This suggests a southward shift (by 0-20 degrees) of the location of NADW formation sites. A larger southward shift is found in those models which have a larger decrease in the overturning strength. Also, a larger southward shift occurs in models that have a more southern location of the downward branch in the control state.

The depth of the main circulation cell associated with the formation of NADW reduces (by $0.5-1 \mathrm{~km}$ ) in those simulations that show a pronounced decrease in $\Psi_{\max }$. At the same time the deep reversed cell intensifies in those models during the LGM and AABW extends to shallower depths, although remaining mostly at latitudes south of $40-50^{\circ} \mathrm{N}$. Models that have a deeper main cell in the control state show a stronger shoaling (or less deepening) during the LGM.
We thus find reasonable agreeement with the data in the response of the overturning strength and the depth of the main cell for about half of the participating models. All models reduce the northward extent of the main cell during the LGM. We conclude at this point that there is a weak dependence of $\Delta \Psi_{\max }$ on the control state: a relatively northern location of the downward branch and a shallow main cell seem to favour an intensified AMOC during the LGM, which extends far north and does not shoal. Other processes influencing $\Delta \Psi_{\max }$ will be discussed in the following two sections.

The different AMOC characteristics discussed here show, in general, a consistent pattern in their response to glacial conditions: a reduced overturning strength goes with a stronger southward shift of the downward branch and a shoaling of the main cell, together with an intensification of the deep reversed cell, and the reversed pattern of change occurs for increased overturning strength. Exceptions are the two experiments where $\Psi_{S}$ increases in absolute value (Hadl2 and Hadl1.5), while the main cell deepens or remains at the same level. However, $\Delta \Psi_{S}$ is small in these runs. It follows that in current climate models changes in the relative contribution of AABW as compared to NADW on the one hand, and changes in oceanic volume transport on the other hand, are equivalent measures of the AMOC response to glacial conditions. Therefore we will discuss the response in only one characteristic in the following, namely that in the maximum overturning strength.

\section{The Atlantic freshwater budget}

As a first step in the analysis this section examines the response of net evaporation over the Atlantic basin, which has been hypothesized to strongly affect the response in AMOC strength (Schmittner et al., 2002). The water loss due to net 
evaporation should be balanced by oceanic transports into the basin (Rahmstorf, 1996). We consider all terms in the freshwater budget rather than just the surface freshwater forcing, as any change in one term will affect the other terms of the budget in order to achieve equilibrium.

\subsection{The terms of the freshwater budget}

The Atlantic freshwater budget consists of a surface flux component (net evaporation) and several oceanic components (transport through the boundaries). Mass conservation imposes that in equilibrium all components should balance:

$\left[E_{\mathrm{net}}\right]=M_{\mathrm{ov}}+M_{\mathrm{az}}+M_{\mathrm{dif}}+M_{\mathrm{BS}}$.

Here the surface flux contribution $\left[E_{\text {net }}\right]$ is the net basinintegrated result of evaporation, precipitation, continental run-off, ice-melt and brine rejection. It also includes any water flux correction, if this is applied in a particular model. The meridional overturning component $M_{\mathrm{ov}}$ and azonal component $M_{\mathrm{az}}$ of the oceanic freshwater transport through the southern boundary are defined as (Rahmstorf, 1996; Weijer et al., 1999):

$M_{\mathrm{ov}}=-\frac{1}{S_{0}} \int d z \bar{v}(z)\left[<S(z)>-S_{0}\right]$,

$M_{\mathrm{az}}=-\frac{1}{S_{0}} \int d z \overline{v^{\prime}(z) S^{\prime}(z)}$,

where $S_{0}$ (34.7 PSU) is a reference salinity, the overbar and the brackets $<$. $>$ denote zonal integration and zonal averaging, respectively, and $v^{\prime}$ and $S^{\prime}$ are deviations from zonal means. The other terms of Eq. (1) represent contributions from diffusion at the southern boundary and transport through Bering Strait. The southern border of the Atlantic basin ranges from 31.5 to $34.5^{\circ} \mathrm{S}$ in the different ocean GCMs. It is taken to be at $40^{\circ} \mathrm{S}$ in the CLIMBER-2 zonalmean ocean component, as the closure coefficient between the meridional and zonal pressure gradient is reduced by three orders of magnitude at this latitude.

In the present analysis we compute $M_{\mathrm{ov}}$ and $M_{\mathrm{az}}$ from the monthly output (mean seasonal cycle) of the 3-D fields of northward velocity $v$ and ocean salinity $S$ that are available in the PMIP database. The run length that is used to compute the mean seasonal cycle ranges from 10-100 yr. Comparison for ECBilt with results based on 100-year timeseries of daily output indicates that this is fairly accurate. The total freshwater flux $\left[E_{\text {net }}\right]$ is also available from the database, but for most models not its separate components. The Bering Strait and diffusive contributions are determined as rest term $R=\left[E_{\mathrm{net}}\right]-M_{\mathrm{ov}}-M_{\mathrm{az}}$ from Eq. (1), assuming that the freshwater budget has equilibrated. In practice, $R$ also contains a term that is associated with the drift in basin-mean salinity in the Atlantic basin. A number of models incorporate the freshwater flow through Bering Strait for the pre-industrial climate, either parameterised as a diffusive transport or explicitly calculated. This transport is mostly set to zero in the LGM simulations, see Table 1.
The overturning component $M_{\mathrm{ov}}$ can be understood as the net freshwater transport carried by the AMOC. For negative values of $M_{\mathrm{ov}}$ the AMOC exports freshwater, even though the Atlantic is a net evaporative basin. The "excess" salt is removed by the azonal component $M_{\mathrm{az}}$, which incorporates the export of surface and thermocline waters via the subtropical gyre. The direction of the overturning freshwater transport is hypothesized to be closely related to the dynamical regime of the AMOC (Rahmstorf, 1996): a northward transport $\left(M_{\mathrm{ov}}\right.$ positive $)$ implies that only the circulation state with NADW formation exists, while a southward transport ( $M_{\mathrm{ov}}$ negative) implies that a stable circulation state without NADW formation is also possible. It is not trivial whether such a conceptual model can be applied to GCMs or the real world. However, numerical experiments with intermediatecomplexity coupled models (Vries and Weber, 2005; Marsh et al., 2007) have confirmed this hypothesis by showing that the bifurcation between the monostable and bistable regime occurs at $M_{\mathrm{ov}} \simeq 0$. Based on these studies, we propose $M_{\mathrm{ov}}$ as a diagnostic for the existence of a stable collapsed AMOC in an ocean model.

\subsection{The pre-industrial and glacial freshwater budgets}

For the present-day climate $\left[E_{\text {net }}\right]$ is thought to carry a net freshwater transport of 0.2-0.3 Sv out of the Atlantic basin (Pardaens et al., 2003). Net evaporation is positive in all models (Fig. 1), except MRI where it is just below zero. This term is overestimated by $0.1-0.3 \mathrm{~Sv}$ in most simulations. Using inverse-model data Weijer et al. (1999) have suggested that the present-day ocean has $M_{\mathrm{az}}=0.38 \mathrm{~Sv}$ and $M_{\mathrm{ov}}=-0.20 \mathrm{~Sv}$. Most models underestimate the azonal term $M_{\mathrm{az}}$ (it is zero by definition in ClimC which only resolves the zonal-mean Atlantic circulation). This is due to an underestimation in most models of the zonal salinity contrast in the southern Atlantic ocean. As a result of high $\left[E_{\text {net }}\right]$ and low $M_{\mathrm{az}}$, the overturning freshwater transport $M_{\mathrm{ov}}$ is misrepresented in most models. It is positive in all models, except ECBilt, which is most likely at variance with observations. In ECBilt the zonal salinity contrast in the southern Atlantic ocean is corrected by local flux corrections, which results in increased $M_{\mathrm{az}}$ and a negative value for $M_{\mathrm{ov}}$ (Vries and Weber, 2005).

The rest term is small enough in most models to assume that diffusion and remaining imbalances play a secondary role. However, for some models the freshwater budget has not yet fully equilibrated. This implies that the budget terms might change when continuing these runs over longer integration times and only preliminary conclusions can be drawn from the present results. Freshwater is not conserved in the UTor model, giving rise to a weak secular variation in mean ocean salinity (Peltier and Solheim, 2003).

The differences (LGM minus pre-industrial values) show a reduction of net evaporation in the cold LGM climate in all PMIP simulations, except Hadl1.5 and MRI. The changes are 

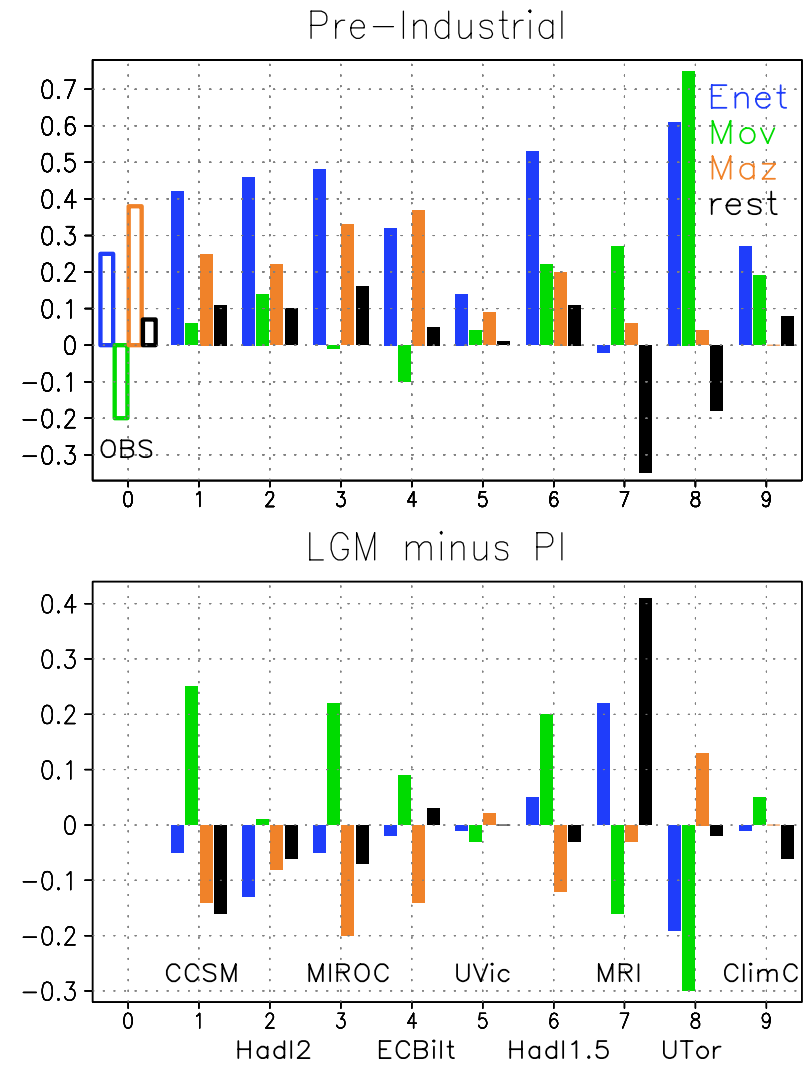

Fig. 1. The terms of the Atlantic freshwater budget as defined in Eq. (1) for the pre-industrial control state (upper panel) and the difference between the LGM and the control state (lower panel) for the nine PMIP simulations as indicated on the horizontal axis. The terms (in Sv) are net evaporation (blue), the overturning (green), azonal (orange) and rest term (black). Open bars denote "observed" values, see text.

most pronounced in Hadl2 and UTor, where [ $\left.E_{\text {net }}\right]$ is reduced by $0.1-0.2 \mathrm{~Sv}$, and in MRI, where [ $\left.E_{\text {net }}\right]$ increases by $0.2 \mathrm{~Sv}$. In all other models, there are larger changes in the ocean transport terms than in the surface flux term. The ocean overturning transport increases (considerably) in most models, whereas the azonal component is mostly reduced during the LGM. Those models that close Bering Strait during the LGM mostly show a reduction in the amplitude of the rest term. It clearly follows from Fig. 1 (lower diagram) that the response in the Atlantic freshwater budget and the associated response in basin-scale salinity is primarily determined by oceanic processes. The surface freshwater flux (integrated over the basin) plays a secondary role. This implies that for most models basin-scale changes in, for example, precipitation, river run-off or sea-ice formation do not significantly affect the Atlantic freshwater budget.
4.3 The surface freshwater forcing as a function of latitude

There is local net evaporation in the subtropics, while there is local net precipitation in the equatorial region and in the mid-high latitudes in all pre-industrial control simulations, broadly consistent with observations. The meridionallyintegrated values are shown in Fig. 2 as a function of latitude. In the northern part of the Atlantic basin the integrated values are negative (net precipitation) up to ca. $20^{\circ} \mathrm{N}$ in all models, except MRI. However, the basin-integrated value is positive (net evaporation), because of the subtropical evaporation zones which dominate over the net precipitation at mid-high latitudes and in the equatorial region. The EMICs underestimate the amplitude of latitudinal variations, but capture the basic pattern. In the UTor run $\left[E_{\text {net }}\right]$ is overestimated considerably, because the tropical precipitation belt is almost completely absent in this model. The latitudinal variations of net evaporation generated by the atmospheric part of the MRI model are basically similar to the other models, but the local flux adjustment is quite large especially over the northern Atlantic. The latitudinal profile of the surface freshwater forcing given to the OGCM is, therefore, more complex in the MRI model.

Latitudinal response patterns (Fig. 2) show a southward shift of the northern Atlantic net precipitation in six models (CCSM, Hadl2, MIROC, MRI, UTor and ClimC), with decreased high-latitude net precipitation and increased midlatitude net precipitation during the LGM as compared to the control run. However, in most models the net effect is small. Only in the UTor simulation there is a clear increase of the mid-high latitude net precipitation during the LGM. Of the three other models ECBilt and UVic show an increased net precipitation over the northern Atlantic, while there is little change in the Hadl1.5 simulation. Over the equatorial and southern Atlantic ocean all models seem to show a latitudinal pattern of reduced subtropical evaporation as well as reduced tropical precipitation, with amplitudes varying among the different models. The basin-integrated value $\left[E_{\text {net }}\right]$ is thus the result of a subtle balance between different processes. It shows little change during the LGM (less than $0.05 \mathrm{~Sv}$ ) in all simulations except Hadl2, MRI and UTor. The latitudinal distribution in Hadl2 indicates that reduced subtropical evaporation in the colder LGM climate plays a major role in reducing $\left[E_{\text {net }}\right]$ in this model, while both reduced subtropical evaporation and increased mid-high latitude precipitation are important for UTor. In the MRI simulation tropical precipitation reduces considerably during the LGM, so that $\left[E_{\text {net }}\right]$ increases.

\subsection{The ocean transport through the southern boundary}

Simulated salinity profiles at the southern border of the Atlantic ocean are shown in Fig. 3. All models, except UTor, simulate very saline surface and thermocline waters, below which relatively fresh Antarctic intermediate waters lie. The 

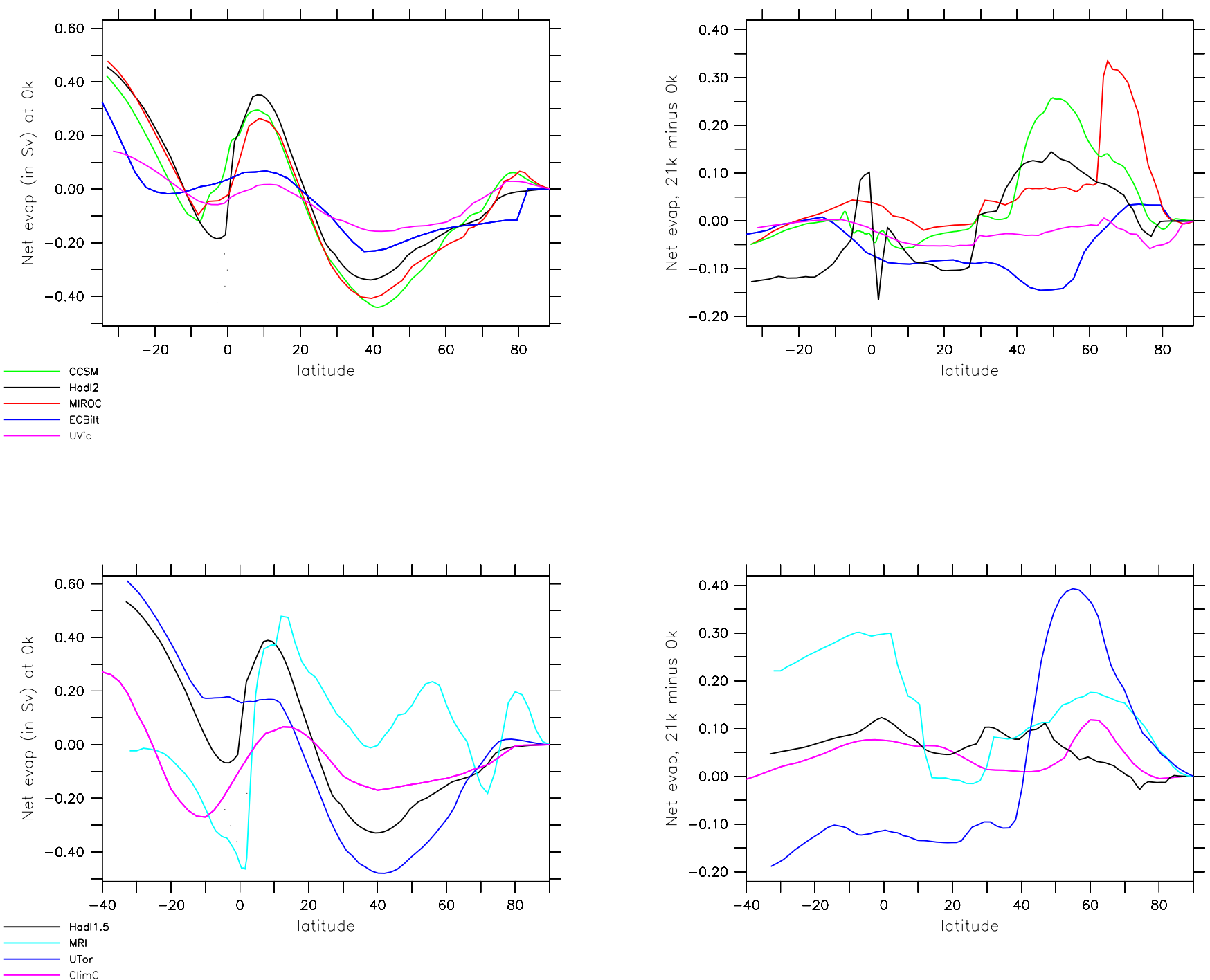

Fig. 2. Meridionally-integrated net evaporation over the Atlantic basin as a function of latitude for the pre-industrial control state (upper left panel) and the difference between the LGM and the control state (upper right panel) for the PMIP2 simulations: CCSM (green), Hadl2 (black), MIROC (red), ECBilt (dark blue) and UVic (purple). Same for the PMIP1.5-type simulations (lower panels): Had11.5 (black), MRI (light blue), UTor (dark blue) and ClimC (purple). The integration starts at $90^{\circ} \mathrm{N}$ (compare Fig. 1 for the values at the southern border).

upper "limb" of the AMOC consists of these waters flowing northward while undergoing transformations due to, for example, the surface freshwater forcing. The lower "limb", NADW flowing southward, lies roughly between $1000 \mathrm{~m}$ and $3000 \mathrm{~m}$ depth (compare Table 2). In most models it is more saline than the upper limb for the modern climate, as indicated by the positive value of $M_{\mathrm{ov}}$ (the AMOC imports freshwater). Antarctic bottom water is slightly fresher than NADW in most PMIP2 simulations, but has varying salinity in PMIP1.5 runs. For comparison the observed salinity profile (Levitus et al., 1994) is shown as well in Fig. 3. Most models capture the vertical structure seen in the data rather well, although the sharp contrast between surface and thermocline waters is generally underestimed. The salinity contrast between AABW and NADW is misrepresented in a number of models as compared to the data. In these simulations NADW and AABW have similar salinity (Hadl1.5 and ClimC) or AABW is even more saline than NADW (Hadl2, UTor).

During the LGM most models simulate somewhat fresher surface and thermocline waters and more saline water at deeper levels. The response is most pronounced in CCSM, which simulates an increase of 0.5-1.7 PSU in Atlantic water masses below ca. $1000 \mathrm{~m}$ (not taking the globalmean increase by 1 PSU in this model into account). Most models simulate a stronger increase in salinity in AABW 

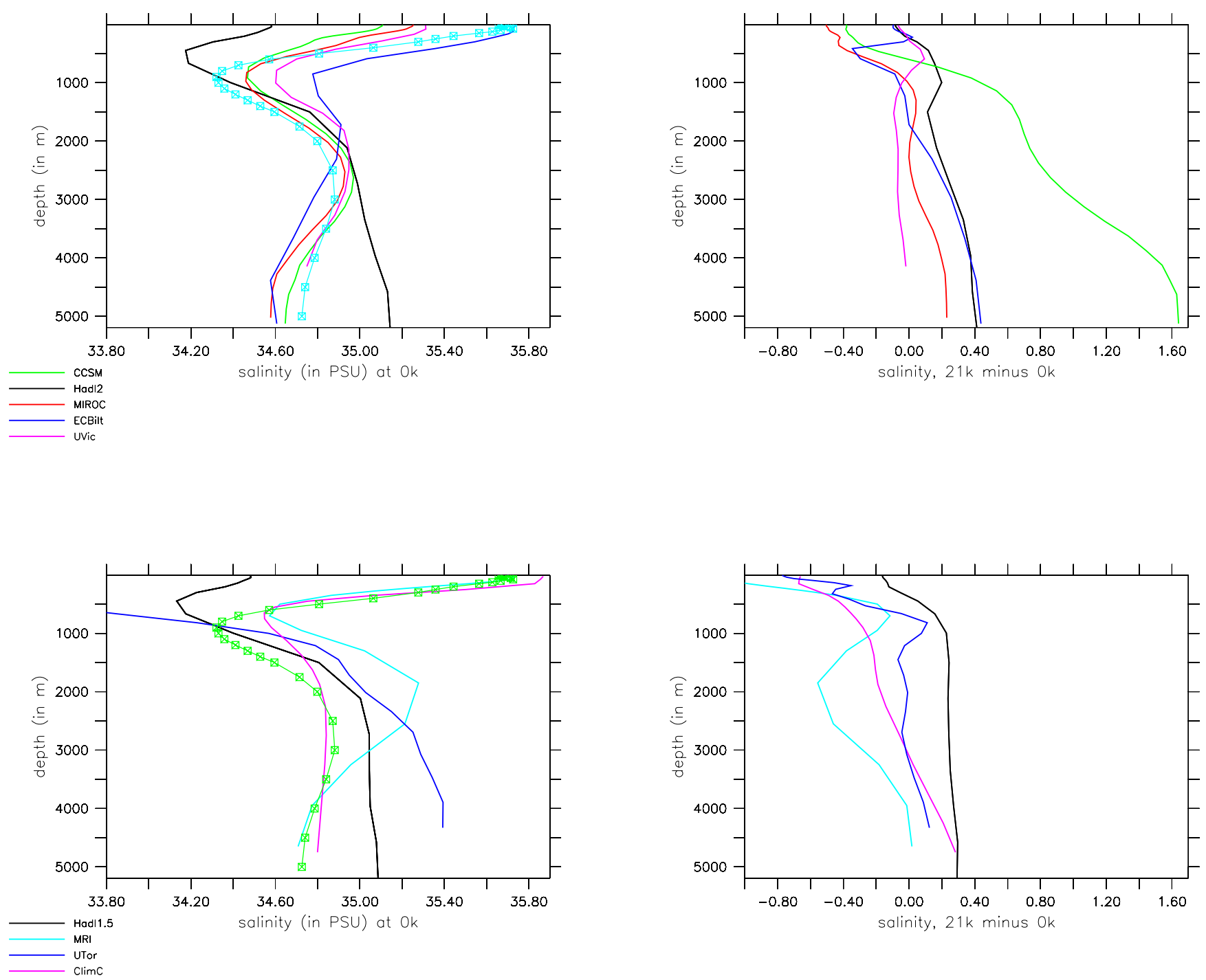

Fig. 3. The zonal-mean salinity at the southern border of the Atlantic basin as a function of depth for the control state (upper left panel) and the difference between the LGM and the control state (upper right panel) for the PMIP2 simulations. Same for the PMIP1.5-type simulations (lower panels). Color coding as in Fig. 2. Levitus salinity profiles (left panels) are marked by squares. The global-mean 1 PSU increase for the LGM in the CCSM model has been subtracted from the model output in order to facilitate comparison with the other models.

than in NADW. In the ClimC simulation AABW becomes more saline, while NADW even freshens. In some models (MIROC, UVic, UTor) changes in deep-ocean salinity are minor. The MRI model shows a freshening at all levels.

Most models simulate a larger $M_{\mathrm{ov}}$ during the LGM, because the fresh upper limb of the AMOC freshens and the saline lower limb becomes more saline. This effect is so strong, that a larger $M_{\mathrm{ov}}$ is even found in those models that simulate a decrease in the overturning strength. It can be amplified by a strong intensification of the AMOC as, for example, in the MIROC run. Only in case of a pronounced decrease in $\Psi_{\max }$ there is a decrease in the overturning transport term (UVic, UTor). In the MRI run $M_{\mathrm{ov}}$ decreases, because the lower AMOC branch freshens.
Significant contributions to $M_{\mathrm{az}}$ come from depths above ca. $700 \mathrm{~m}$. This is in accordance with the longitudinal variations of salinity being appreciable only at those depths. All models exhibit a salinity maximum near the South American continent, resulting in a positive $M_{\mathrm{az}}$ for the control climate. The azonal component becomes smaller during the LGM compared to modern in most models. This is mainly due to a reduced zonal contrast in the southern Atlantic ocean salinity, while the gyre circulation intensifies. In two models (UVic and UTor) the azonal salinity contrast becomes stronger, resulting in an enhanced azonal transport. 


\subsection{Preliminary conclusions}

Changes in the overturning freshwater transport are clearly not a good diagnostic for changes in AMOC strength, as $\Delta M_{\mathrm{ov}}$ is mostly positive or close to zero irrespective of $\Delta \Psi_{\max }$. Also, we cannot attribute the change in AMOC strength to one of the other components of the freshwater budget. It seems that none of these terms can be seen as the main driver for the changes in Atlantic overturning. So we reject the earlier hypothesis that changes in Atlantic net evaporation primarily cause changes in Atlantic overturning, when comparing modern and LGM values. Clearly, the Atlantic overturning does not operate in isolation and is not forced locally by the Atlantic freshwater budget. The most likely candidate from outside to drive changes in the Atlantic overturning seems to be the Southern Ocean overturning cell involving AABW formation. There is a remarkable anticorrelation between the response in this cell and that in the overturning strength (compare Table 2). In the next section we will evaluate the interaction between the Southern Ocean and Atlantic overturning cells in more detail.

The response of the overturning transport term to glacial conditions does give an indication of the dynamical regime of the AMOC. During the LGM most models have positive $M_{\mathrm{ov}}$, implying that they are in the monostable regime (on the thermohaline branch in the hysteresis diagram). Monostability of the glacial AMOC was already demonstrated by Ganopolski and Rahmstorf (2001) in the CLIMBER-2 model, where a collapsed LGM state does not exist (but which allows for two closely-related modes with an active AMOC during the LGM). Also, the glacial AMOC was found to be monostable in experiments with an ocean-only model by Prange et al. (2002). The present results suggest that most models exhibit similar behavior.

For two models (ECBilt and UVic) $M_{\mathrm{ov}} \simeq 0$ for the LGM state. Based on this value, we hypothesize that in these models the LGM state is very close to the bifurcation point between the monostable regime (thermohaline branch) and bistable regime (thermal branch). This might cause a strongly nonlinear response to the imposed LGM forcings and boundary conditions.

\section{Southern Ocean controls versus Atlantic processes}

In this section we examine the AMOC response during the LGM, focussing on the role of processes within the Atlantic basin versus those originating in the Southern Ocean. To characterise the controlling processes within the Atlantic basin, we examine the response in both net evaporation [ $\left.E_{\text {net }}\right]$ and the density difference $\rho_{\text {Atl }}$ between the northern and southern ends of the Atlantic basin. The density difference, which is ultimately generated by local fluxes of heat and freshwater at the ocean surface, has been found to scale linearly with the overturning strength in a number of modelling studies (Hughes and Weaver, 1994; Rahmstorf, 1996; Thorpe et al., 2001). If the AMOC response is controlled by Atlantic processes, then one expects $\Delta \Psi_{\max }$ to scale with $\Delta\left[E_{\text {net }}\right]$ and $\Delta \rho_{\text {Atl }}$. On the other hand, if the competition between NADW and AABW plays a major role (Ganopolski et al., 1998; Shin et al., 2003) such scaling behavior is less likely.

In the following the Atlantic north-south density difference $\rho_{\text {Atl }}$ is computed as the difference between the zonaland depth mean density in the northern Atlantic (at $55^{\circ} \mathrm{N}$ ) and at the southern end of the Atlantic basin (taken at $30^{\circ} \mathrm{S}$ in all models). The former is assumed to characterise the density of NADW at its source region, as the location of the sinking branch of the meridional overturning cell associated with NADW is roughly at this latitude. The depth average is taken over depths between the surface and $1500 \mathrm{~m}$. The latter depth level lies within the body of southward flowing NADW for most models at the two time periods. This choice of level of integration was found to be adequate for the HadCM3 model (Thorpe et al., 2001), while no sensitive dependence of the scaling relation on the depth level was found by Rahmstorf (1996). The zonal- and depth mean densities at the northern and southern ends of the Atlantic basin are shown for each simulated control state in Fig. 4 (upper left panel), together with estimates based on observed temperature and salinity data (Levitus and Boyer, 1994; Levitus et al., 1994). The majority of models lies reasonably close to the observed data, with the northern values considerably larger than the southern ones.

Changes in the overturning strength scale with $\Delta \rho_{\text {Atl }}$ in only two out of nine models (Fig. 4, lower left panel): an increased $\rho_{\text {Atl }}$ gives rise to a stronger overturning in MIROC, while a decreased $\rho_{\text {Atl }}$ and reduced $\Psi_{\text {max }}$ are found in UTor. In the seven other models, the response in the density difference is either small (Hadl2, UVic, Hadl1.5 and MRI) or it works against the response in overturning strength (CCSM, ECBilt and ClimC). Examination of the north-south temperature and salinity differences (Fig. 4, middle panels) does not show a consistent response among the different models. The northern part of the Atlantic basin cools more than the southern part in some models, and vice versa in others. Also, the northern Atlantic freshens in some models and becomes more saline in others compared to the southern part. The relative contribution of changes in temperature and salinity to changes in the north-south density difference is indicated in the figure (right-hand scale). For most models temperature and salinity effects are equally important.

Changes in the overturning strength are plotted against changes in net evaporation in Fig. 4 (upper right panel). There is mostly a clear relationship between the sign of $\Delta \Psi_{\max }$ and $\Delta\left[E_{\text {net }}\right]$. However, the amplitude of changes in AMOC strength does not seem to depend much on the amplitude of changes in $\left[E_{\text {net }}\right]$. These results indicate that small changes in the freshwater forcing (of $0.05 \mathrm{~Sv}$ and less) during the LGM as compared to modern are not decisive for the simulated AMOC response. However, a strong reduction or 

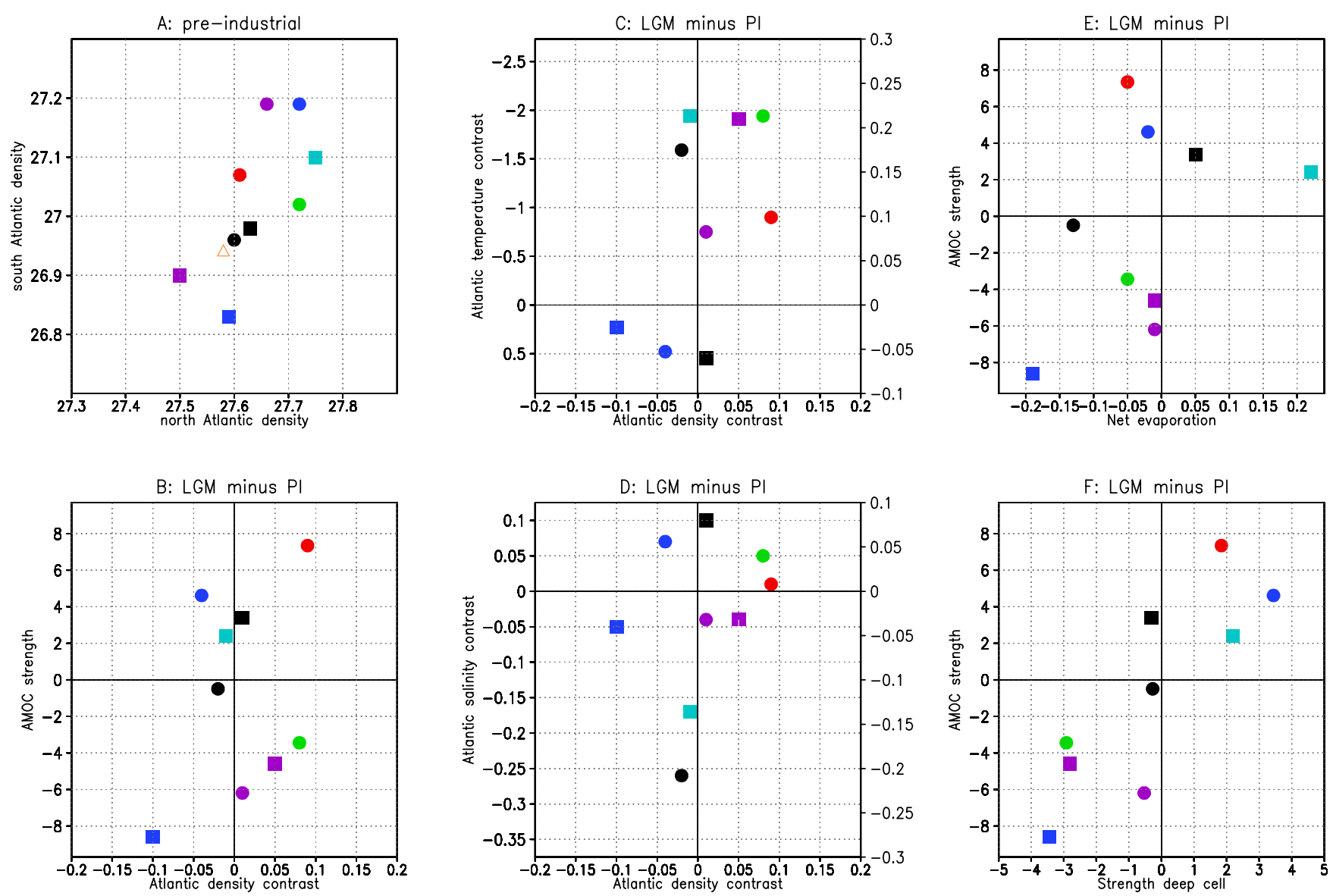

Fig. 4. Analysis of processes within the Atlantic basin for the PMIP2 (circles) and PMIP1.5 (squares) simulations: CCSM (green), Hadl2 (black), MIROC (red), ECBilt (dark blue), UVic (purple), Hadl1.5 (black), MRI (light blue), UTor (dark blue) and ClimC (purple). (A) The density at the southern end of the Atlantic basin versus that at the northern end for the pre-industrial control runs, with an estimate based on the Levitus data (orange triangle) and (B) The response in AMOC strength versus that in the Atlantic density contrast. The middle panels ( $\mathbf{C}$ and $\mathbf{D})$ give the response in the Atlantic temperature and salinity contrast (left-hand scale in K and PSU) versus that in the density contrast. The separate impact of the temperature and salinity response on the density response is estimated using the equation of state with a fixed salinity of 34.7 PSU and a fixed temperature of $275 \mathrm{~K}$, respectively (right-hand scale in $\mathrm{kg} / \mathrm{m}^{3}$; the vertical range is the same in both panels). The right-hand panels ( $\mathbf{E}$ and $\mathbf{F}$ ) give the response in AMOC strength versus that in net evaporation over the Atlantic basin (E) and the strength of the deep reversed cell $(\mathrm{F})$. Densities are given in $\mathrm{kg} / \mathrm{m}^{3}$ (relative to a reference value of 1000), circulation strengths and evaporation in Sv.

increase in [ $\left.E_{\text {net }}\right]$ (as in Hadl2, MRI and UTor) clearly contributes toward a MOC reduction or increase.

As already discussed in Sect. 3, the strength of the deep reversed cell increases (decreases) consistently with reduced (increased) $\Psi_{\max }$ for the LGM climate as compared to the control climate in all simulations except Hadl1.5 (lower right panel). This strongly suggests that changes in AABW density play an important role in controlling changes in the AMOC strength. Therefore, we now consider changes in the density of AABW at its source latitude and associated changes in the reversed circulation cell at depths below ca. $3000 \mathrm{~m}$ in the Atlantic ocean. The density of AABW is characterised here by the zonal-mean density at $55^{\circ} \mathrm{S}$ averaged over all depth levels. The density contrast $\rho_{\mathrm{SN}}$ is defined as the density difference between AABW (at $55^{\circ} \mathrm{S}$ ) and NADW (at $55^{\circ} \mathrm{N}$ ).

The AABW and NADW densities vary greatly among the different models in the control state (Fig. 5, upper left panel). Very dense AABW (at its source region) is found in those models that have relatively saline $\mathrm{AABW}$ at the southern end of the Atlantic basin (Hadl2 and UTor; compare Fig. 3), while in one model (ECBilt) NADW is more dense than AABW (both at their source region). Observations suggest slightly more dense AABW as compared to NADW, as indicated in the Figure.

Changes in $\Psi_{\max }$ are shown versus those in $\rho_{\mathrm{SN}}$ in Fig. 5 (lower left panel). The response in the density contrast is found to be a fairly good predictor for the response in At- 

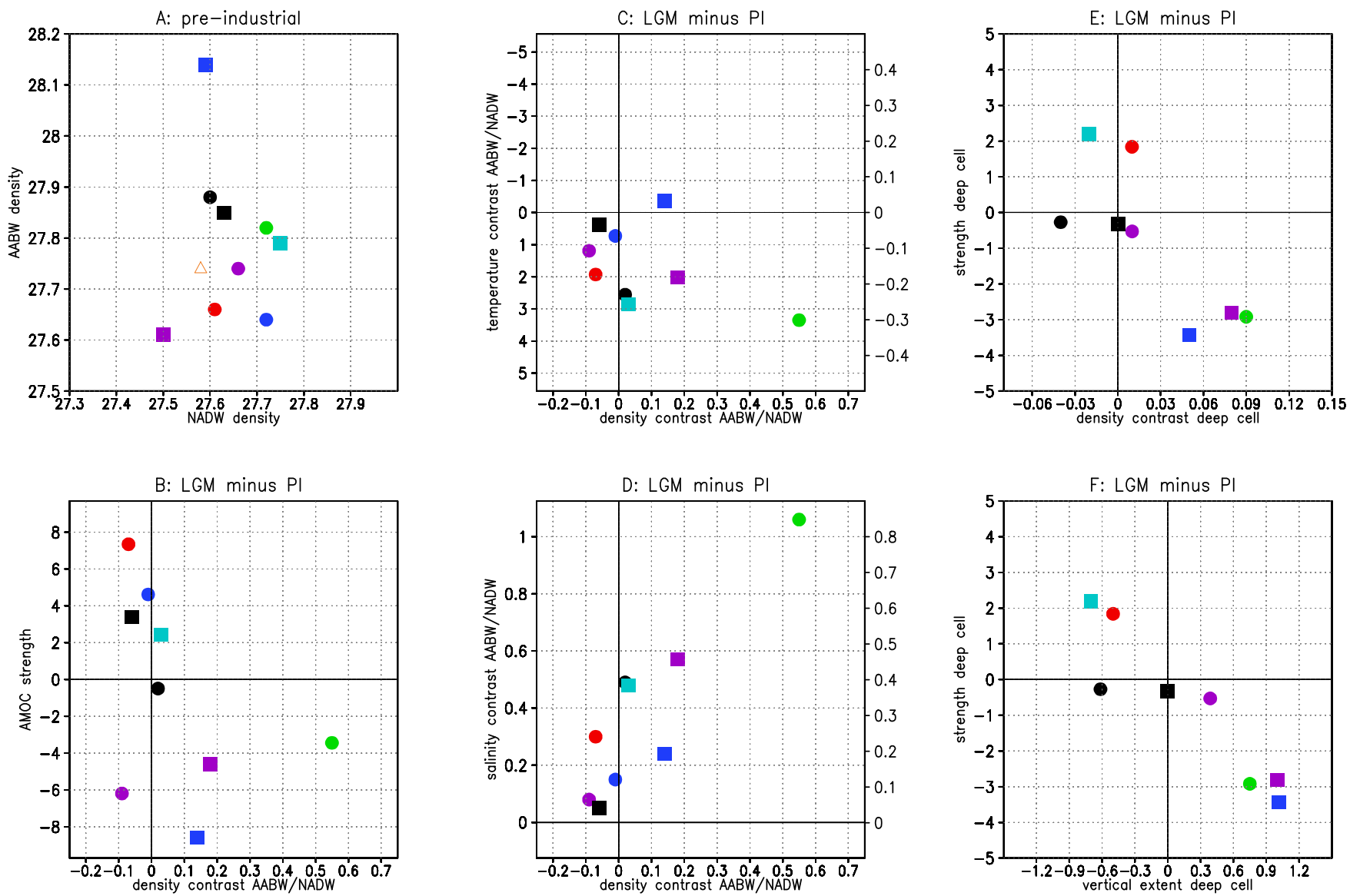

Fig. 5. Analysis of Atlantic processes versus those originating in the Southern Ocean. Colors, symbols and units as in Fig. 4. (A) The density of AABW at its source region versus that of NADW at its source region for the pre-industrial control runs, with an estimate based on the Levitus data (orange triangle) and (B) The response in AMOC strength versus that in the density contrast between AABW and NADW. The middle panels ( $\mathbf{C}$ and $\mathbf{D}$ ) give the response in the temperature and salinity contrast between AABW and NADW (left-hand scale in K and PSU) versus that in the density contrast. The estimated impact on the density contrast is derived as in Fig. 4 (right-hand axis in kg/m ${ }^{3}$ ). The right-hand panels ( $\mathbf{E}$ and $\mathbf{F}$ ) analyse the deep reversed cell associated with the formation of AABW, giving the response in the strength of the deep cell versus that in the deep meridional density contrast (E) and the vertical extent of the deep cell (F).

lantic overturning strength in most models that have a significant change in $\rho_{\mathrm{SN}}$. A relative increase in AABW density is found in CCSM, UTor and ClimC, together with an increased $\Psi_{\mathrm{S}}$ and decreased $\Psi_{\max }$. The reverse is seen in MIROC and Hadl1.5, although changes in $\rho_{\mathrm{SN}}$ are relatively small here. Three models (Hadl2, ECBilt and MRI) have negligible $\Delta \rho_{\mathrm{SN}}$. In one model (UVic) the density contrast reduces, while $\Psi_{\max }$ reduces as well. The response in temperature and salinity contrast between AABW and NADW (middle panels) is more consistent than in case of the Atlantic north-south differences. During the LGM AABW becomes relatively more saline in all models, while it cools less than NADW in all models except one. The opposing effects of a relative temperature increase and salinity increase result in an increased density contrast in some models, but decreased contrast in others. Salinity changes dominate over tempera- ture changes in those models that show a substantial increase in $\rho_{\mathrm{SN}}$ (CCSM, UTor and ClimC). In the other models simulated temperature and salinity changes have a comparable impact on the density contrast.

Table 3 gives a summary of the scaling relationships between $\Delta \Psi_{\max }$ and the response in processes within the Atlantic basin as well as originating from the Southern Ocean. Here a Yes indicates a positive correlation, a No a negative correlation and a blank the absence of a significant response in the process under examination. Although a correlation cannot prove a causal relationship, we can at least deduce a strong indication for such a relationship from it. This is especially true, if one process shows a positive correlation and the other processes show no response or a negative correlation. We conclude here that in a number of models only one process plays a dominant role, while more than one process 
Table 3. Overview of the scaling relationships between $\Delta \Psi_{\max }$ (the response in the AMOC strength) and $\Delta\left[E_{\text {net }}\right]$ (the response in net evaporation), $\Delta \rho_{\text {Atl }}$ (the response in the Atlantic north-south density contrast) and $\Delta \rho_{\mathrm{SN}}$ (the response in the density contrast between AABW and NADW), see Sect. 5 for a discussion. The columns 2-4 give a Yes (No) in the case of a positive (negative) correlation and a blank if there is no significant response. The fifth column summarizes the processes that apparently control $\Delta \Psi_{\max }$ for each model.

\begin{tabular}{lcccc}
\hline & $\Delta\left[E_{\text {net }}\right]$ & $\Delta \rho_{\text {Atl }}$ & $\Delta \rho_{\text {SN }}$ & control \\
\hline PMIP2 & & & & \\
\hline CCSM & & No & Yes & $\rho_{\text {SN }}$ \\
Had12 & Yes & & & {$\left[E_{\text {net }}\right]$} \\
MIROC & & Yes & Yes & $\rho_{\text {Atl }}+\rho_{\mathrm{SN}}$ \\
ECBilt & & No & & \\
UVic & & & No & \\
\hline
\end{tabular}

\begin{tabular}{lcccc}
\hline PMIP1.5 & & & & \\
\hline Had11.5 & & & Yes & $\rho_{\mathrm{SN}}$ \\
MRI & Yes & & & {$\left[E_{\text {net }}\right]$} \\
UTor & Yes & Yes & Yes & {$\left[E_{\text {net }}\right]+\rho_{\text {Atl }}+\rho_{\mathrm{SN}}$} \\
ClimC & & No & Yes & $\rho_{\mathrm{SN}}$ \\
\hline
\end{tabular}

is at work in two models (MIROC and UTor) and none of the examined processes is decisive in two other models (ECBilt and UVic). The response in the density contrast between AABW and NADW plays an important role in five out of nine models.

Finally we consider the response in the intensity of the deep reversed cell itself (Fig. 5, right-hand panels). It is found to scale well with the response in both the deep meridional density contrast and the vertical extent of the deep cell, a relationship which has been derived theoretically by Kamenkovich and Goodman (2000). Here the meridional density contrast is defined as the zonal- and depth mean density at $30^{\circ} \mathrm{S}$ minus that at $25^{\circ} \mathrm{N}$, taking the depth average over the lower $1000 \mathrm{~m}$ for each model. These strong scaling relationships again point to the deep reversed cell as a driving process for the AMOC response to glacial conditions.

Factors that are thought to be important for setting AABW transport are surface salinity at the Antarctic coast (Paul and Schaeffer-Neth, 2003) and mixing by mesoscale oceanic eddies as parameterised by diffusion (Kamenkovich and Goodman, 2000). Three models show a substantial increase in the strength of AABW transport in the present analysis. The salinity contrast between AABW and NADW was found to play a key role (Fig. 5). One of these models shows a salinity increase of glacial AABW at its source region (CCSM), one a freshening of glacial NADW at its source region (UTor) and one seems to be driven by the combined effect of northern freshening and southern salinification during the LGM (ClimC). Interestingly, these models span the full range of ocean model resolution considered here. This implies vary- ing importance of mixing by diffusion. It is thus not possible to relate the response in AABW transport uniquely to an Antarctic source or to the diffusivity in the numerical ocean model.

\section{Discussion and conclusions}

This paper analyses the response of the Atlantic overturning circulation to LGM forcings and boundary conditions in nine PMIP coupled model simulations. Central in the analysis is the question of which mechanism ultimately controls the AMOC response: changes in net evaporation over the Atlantic basin, local processes within the Atlantic basin as expressed by the density difference between the northern and southern ends, or the deep overturning cell associated with the formation of AABW in the Southern Ocean. The results are summarised in Table 3.

In five out of nine simulations (CCSM, MIROC, Hadl1.5, UTor and ClimC) the competition between NADW and $\mathrm{AABW}$ is found to play an important role, either favouring an increase or a decrease in overturning strength. In the two simulations, which have the largest response in $\rho_{\mathrm{SN}}$ (CCSM and ClimC), the controlling process originates exclusively in the competition between southern and northern water masses. The response in the Atlantic density contrast $\rho_{\text {Atl }}$ opposes the AMOC response in these two models, while net evaporation remains close to modern values during the LGM. In the three other models, the response in the Atlantic density contrast $\rho_{\text {Atl }}$ plays a role too (MIROC and UTor) or the response in $\rho_{\mathrm{SN}}$ is relatively small (Hadl1.5). In the former two models $\Delta \rho_{\mathrm{SN}}$ and $\Delta \rho_{\text {Atl }}$ have the same sign, so that it is not possible to distinguish between these two factors. In one of these simulations (Utor) $\Delta\left[E_{\text {net }}\right]$ also contributes toward the simulated AMOC response, whereas it is small in MIROC and Had11.5. In two simulations (Hadl2 and MRI) $\Delta\left[E_{\text {net }}\right]$ seems to be the sole controlling process. Finally, for two simulations (ECBilt and Uvic) it is not possible to identify which process dominates the simulated AMOC response.

We thus find that $\Delta \rho_{\mathrm{SN}}$ is a major controlling factor. It is determined by the balance between a relative increase in AABW salinity versus a relative warming (less cooling) as compared to NADW during the LGM. More saline AABW during the LGM is consistently found in all simulations, but the amplitude of the signal varies considerably. A strong increase as suggested by Adkins et al. (2002) is only found in CCSM. In this model the salinity increase is attributed to seaice expansion rather than changes in local evaporation and precipitation (Shin et al., 2003). Further research is needed to establish whether this mechanism is unique to the CCSM model or whether it is also present in other models, but less active than in CCSM.

It is remarkable that net evaporation over the Atlantic basin only plays a dominant role in two simulations. In one of these (Hadl2) the reduction in $\left[E_{\text {net }}\right]$ during the LGM is partly 
due to an imposed freshwater flux at high northern latitudes. In the earlier HadCM run (Hadl1.5), which did not contain such a freshwater forcing, the AMOC response is linked to changes in density contrasts rather than $\Delta\left[E_{\text {net }}\right]$. Although evaporation decreases in the colder LGM climate, precipitation and run-off also decrease resulting in a small net effect in most simulations. Interestingly, most models that have a AMOC reduction during the LGM show a decrease in net precipitation over the northern Atlantic ocean. This implies that it is definitely not a high-latitude freshening of the Atlantic basin which causes the glacial AMOC reduction.

There seems to be some dependence of the glacial AMOC response on the accuracy of the control state. Models that have a too shallow main circulation cell in the Atlantic basin do not show further shoaling during the LGM. Also, a southern location of the downward branch seems to favour a stronger southward shift during the LGM. A few models have too dense $\mathrm{AABW}$ in their control simulation compared to observations. This clearly affects the response to glacial conditions, resulting in a strong presence of $\mathrm{AABW}$ in the Atlantic basin during the LGM.

It is not possible to pinpoint the controlling mechanism in two simulations (ECBilt and UVic). Changes in the controlling factors discussed above are too small to attribute the relatively large AMOC changes found in these two models to any of them. In the case of ECBilt the very low density of $\mathrm{AABW}$ in the control climate may play a role, favouring an intensified glacial AMOC. Both models have an overturning freshwater transport close to zero during the LGM, indicating that these models are close to the bifurcation point where the collapsed AMOC exists (Rahmstorf, 1996: Vries and Weber, 2005). This may give rise to a strongly nonlinear response, in agreement with the large AMOC changes associated with the small changes in the controlling factors found in these models.

Summarising, we find a variety of AMOC responses to glacial conditions. About half of the models shows a response that is consistent with the classical view of a stronger glacial AABW inflow into the Atlantic basin and a reduced NADW formation. However, sites of proxy data are sparsely distributed and the interpretation of the data is difficult (see Roche et al. (2006) for an overview). Therefore, this might be revised as more data becomes available and better interpretation techniques are developed. On the modelling side, existing climate models still have relatively coarse resolution and most have fixed diffusion coefficients, while they do not take changes in the energy available for mixing due to winds and tides into account. Inclusion of a physically more realistic representation of mixing might modify the glacial AMOC response in climate models (Wunsch, 2006). Considering these caveats, we conclude that the diversity of AMOC responses indicates disagreement with the data for a number of state-of-the art climate models. Although the competition between water masses of southern and northern origin emerges as a major controlling factor, other factors (net evaporation, accuracy of the control state) cannot be ruled out. Based on these results, it seems inconclusive whether existing climate models have the accuracy to simulate AMOC changes in response to future increases in greenhouse gas levels.

Acknowledgements. The Laboratoire des Sciences du Climat et de l'Environnement (LSCE) is acknowledged for collecting and archiving the model output. The PMIP2 Data Archive (http://www-lsce.cea.fr/pmip2/) is supported by CEA, CNRS, the EU project MOTIF (EVK2-CT-2002-00153) and the Programme National d'Etude de la Dynamique du Climat (PNEDC). The analyses were performed using output available at 29-08-2006. This research was partly funded by the MOTIF project. Michael Kliphuis is thanked for developing the budget analysis software. We thank A. Paul and one anonymous referee for constructive and useful reviews.

Edited by: J. Hargreaves

\section{References}

Adkins, J. F., McIntyre, K., and Schrag, D. P.: The salinity, temperature and $\delta^{18} \mathrm{O}$ of the glacial deep ocean, Science, 298, 17691773, 2002.

Curry, W. B. and Oppo, D. W.: Glacial water mass geometry and the distribution of $\delta^{13} \mathrm{C}$ of $\Sigma \mathrm{CO}_{2}$ in the western Atlantic ocean, Paleoceanography, 20, 1017-1028, 2005.

Dickson, R. R. and Brown, J.: The production of North Atlantic Deep Water: Sources, rates and pathways, J. Geophys. Res., 99(C6), 12 319-12 341, 1994.

Duplessy, J. C., Shackleton, N. J., Fairbanks, R. G., Labeyrie, L., Oppo, D. W., and Kallel, N.: Deep water source variations during the last climatic cycle and their impact on the global deep water circulation, Paleoceanography, 3, 343-360, 1988.

Ganopolski, A. and Rahmstorf, S.: Rapid changes of glacial climate simulated in a coupled model, Nature, 409, 153-158, 2001.

Ganopolski, A., Rahmstorf, S., Petoukhov, V., and Claussen, M.: Simulation of modern and glacial climates wih a coupled global model of intermediate complexity, Nature, 391, 351-356, 1998.

Gordon, C., Cooper, C., Senior, C. A., Banks, H., Gregory, J. M., Johns, T. C., Mitchell, J. F. B., and Wood, R. A.: The simulation of SST, sea-ice extents and ocean heat transports in a version of the Hadley Centre coupled model without flux adjustments, Clim. Dyn., 16, 147-168, 2000.

Gregory, J., Dixon, K. W., Stouffer, R. J., Weaver, A. J., Driesschaert, E., Eby, M., Fichefet, T., Hasumi, H., Hu, A., Jungclaus, J. H., Kamenkovich, I. V., Levermann, A., Montoya, M., Murakami, S., Nawrath, S., Oka, A., Solokov, A. P., and Thorpe, R. B.: A model intercomparison of changes in the Atlantic thermohaline circulation in response to increasing atmospheric $\mathrm{CO}_{2}$ concentration, Geophys. Res. Lett., 32, L12703, doi:10.1029/2005GL023209, 2005.

Hargreaves, J. C., Abe-Ouchi, A., and Annan, J. D.: Linking glacial and future climates through an ensemble of GCM simulations, Clim. Past Discuss., 2, 951-977, 2006, http://www.clim-past-discuss.net/2/951/2006/.

Hasumi, H. and Emori, S.: K-1 coupled model (MIROC) description, K-1 technical report 1, Center for Climate System Research, University of Tokyo, 2004. 
Hewitt, C. D., Broccoli, A. J., Mitchell, J. F., and Stouffer, R. J.: A coupled model study of the last glacial maximum: was part of the North Atlantic relatively warm?, Geophys. Res. Lett., 28, 1571-1574, 2001.

Hughes, T. M. C. and Weaver, A. J.: Multiple equilibria of an asymmetric two-basin ocean model, J. Phys. Oceanogr., 24, 619-637, 1994.

Kageyama, M., Laine, A., Abe-Ouchi, A., Braconnot, P., Cortijo, E., M. Crucifix, M., de Vernal, A., Guiot, J., Hewitt, C. D., Kitoh, A., Marti, O., Ohgaito, R., Otto-Bliesner, B., Peltier, W. R., Rosell-Mele, A., Vettoretti, G., Weber, S. L., and MARGO Project Members: Last Glacial Maximum temperatures over the North Atlantic, Europe and western Siberia: a comparison between PMIP models, MARGO sea-surface temperatures and pollen-based reconstructions, Quatern. Sci. Rev., 25(17-18), 2082-2102, 2006.

Kamenkovich, I. V. and Goodman, P. J.: The dependence of AABW transport in the Atlantic on vertical diffusivity, Geophys. Res. Lett., 27, 3739-3742, 2000.

Kitoh, A., Murakami, S., and Koide, H.: A simulation of the Last Glacial Maximum with a coupled atmosphere-ocean GCM, Geophys. Res. Lett., 28, 2221-2224, 2001.

Labeyrie, L. D., Duplessy, J.-C., Duprat, J., Juillet-Leclerc, A., Moyes, J., Michel, E., Kallel, N., and Shackleton, N. J.: Changes in the vertical structure of the North Atlantic ocean between glacial and modern times, Quatern. Sci. Rev., 11, 401-413, 1992.

LeGrand, P. and Wunsch, C.: Constraints from paleotracer data on the North Atlantic circulation during the last glacial maximum, Paleoceanography, 6, 1011-1045, 1995.

Levitus, S. and Boyer, T. P.: World Ocean Atlas 1994 Volume 4: Temperature. NOAA ATLAS NESDIS 4. U.S. Government Printing Office, 1994.

Levitus, S., Burgett, R., and Boyer, T. P.: World Ocean Atlas 1994 Volume 3: Salinity. NOAA ATLAS NESDIS 3. U.S. Government Printing Office, 1994.

Marsh, R., Hazeleger, W., Yool, A., and Rohling, E. J.: Stability of the Thermohaline Circulation under millennial $\mathrm{CO}_{2}$ forcing and two alternative controls on Atlantic salinity, Geophys. Res. Lett., in press, 2007.

Masson-Delmotte, V., Kageyama, M., Braconnot, P., Charbit, S., Krinner, G., Ritz, C., Guilyardi, E., Jouzel, J., Abe-Ouchi, A., Crucifix, M., Gladstone, R. M., Hewitt, C.D., Kitoh, A., Legrande, A.N., Marti, O., Merkel, U., Motoi, T., Ohgaito, R., Otto-Bliesner, B., Peltier, W. R., Ross, I., Valdes, P.J., Vettoretti, G., Weber, S. L., Wolk, F., and Yu, Y.: Past and future polar amplification of climate change: climate model intercomparison and ice-core constraints, Clim. Dyn., 26(5), 513-529, doi:10.1007/s00382-005-0081-9, 2005.

McManus, J., Francois, R., Gherardi, J., Keigwin, L., and BrownLeger, S.: Collapse and rapid resumption of Atlantic meridional circulation linked to deglacial climate changes, Nature, 428, 834-837, 2004

Otto-Bliesner, B., Brady, E. C., Clauzet, G., Tomas, R., Levis, S., and Kothalava, Z.: Last Glacial Maximum and Holocene climate in CCSM3, J. Clim., 19, 2526-2544, 2006.

Pardaens, A. K., Banks, H. T., Gregory, J. M., and Rowntree, P. R.: Freshwater transports in HadCM3, Clim. Dyn., 21, 177-195, 2003.

Paul, A. and Schaefer-Neth, C.: Modeling the water masses of the
Atlantic Ocean at the Last Glacial Maximum, Paleoceanography, 18(3), 1058, doi:10.1029/2002PA000783, 2003.

Peltier, W. R.: Ice age paleotopography, Science, 265, 195-201, 1994.

Peltier, W. R.: Global glacial isostasy and the surface of the ice-age Earth: the ICE-5G (VM2) model and GRACE, Ann. Rev. Earth Plan. Sci., 32, 111-149, 2004.

Peltier, W. R. and Solheim, L. P.: The climate of the Earth at Last Glacial Maximum: statistical equilibrium state and a mode of internal variability, Quatern. Sci. Rev., 23, 335-357, 2004.

Prange, M., Romanova, V., and Lohmann, G.: The glacial thermohaline circulation: stable of unstable?, Geophys. Res. Lett., 29, 2028-2031, 2002.

Rahmstorf, S.: On the freshwater forcing and transport of the Atlantic thermohaline circulation, Clim. Dyn., 12, 799-811, 1996.

Roche, D. M., Dokken, T. M., Goosse, H., Renssen, H., and Weber, S. L.: Climate of the last glacial maximum: sensitivity studies and model-data comparison with the LOVECLIM coupled model, Clim. Past Discuss., 2, 1105-1153, 2006 , http://www.clim-past-discuss.net/2/1105/2006/.

Rutberg, R. L. and Peacock, S. L.: High-latitude forcing of interior ocean $\delta^{13} C$, Paleoceanography, 21, PA2012, doi:10.1029/2005PA001226, 2006

Sarnthein, M., Winn, K., Jung, S. J. A., Duplessy, J.-C., Labeyrie, L., Erlenkeuser, H., and Ganssen, G.: Changes in east Atlantic deepwater circulation over the last 30,000 years: Eight time slice reconstructions, Paleoceanography, 9, 209-267, 1994.

Schmittner, A., Meissner, K. J., Eby, M., and Weaver, A J.: Forcing of the deep ocean circulation in simulations of the Last Glacial Maximum, Paleoceanography, 17, 26-35, doi:10.1029/2001PA000633, 2002.

Shin, S., Liu, Z., Otto-Bliesner, B., Kutzbach, J. E., and Vavrus, S. J.: Southern ocean sea-ice control of the glacial North Atlantic thermohaline circulation, Geophys. Res. Lett., 30, 1096, doi:10.1029/2002GL015513, 2003.

Thorpe, R. B., Gregory, J. M., Johns, T. C., Wood, R. A., and Mitchell, J. F. B.: Mechanisms determining the Atlantic Thermohaline circulation response to Greenhouse Gas forcing in a nonflux-adjusted coupled climate model, J. Clim., 14, 3102-3116, 2001.

Vries, P. de and Weber, S. L.: The Atlantic freshwater budget as a diagnostic for the existence of a stable shut-down of the meridional overturning circulation, Geophys. Res. Lett., 32, L09606, doi:10.1029/2004GL021450, 2005.

Weaver, A. J., Eby, M., Wiebe, E. C., Bitz, C. M., Duffy, P. B., Ewen, T. L., Fanning, A. F., Holland, M. M., MacFadyen, A., Matthews, H. D., Meissner, K. J., Saenko, O., Schmittner, A., Wang, H., and Yoshimori, M.: The UVic Earth System Climate Model: Model description, climatology and application to past, present and future climates, Atmosphere-Ocean, 39, 361-428, 2001.

Weijer, W., de Ruijter, W. P. M., Dijkstra, H. A., and van Leeuwen, P. J.: Impact of interbasin exchange on the Atlantic overturning circulation, J. Phys. Oceanogr., 29, 2266-2284, 1999.

Wunsch, C.: Abrupt climate change: an alternative view, Quatern. Res., 65, 191-203, 2006.

Zahn, R. and Mix, A. C.: Benthic foraminiferal $\delta^{18} O$ in the ocean's temperature-salinity-density field: constraints on the ice age thermohaline circulation, Paleoceanography, 6, 1-20, 1991. 